\title{
Oceňování lesních majetků
}

\author{
Forestry Assets Valuation \\ Vlastimil Vala $^{\mathrm{a}^{*}}$, David Březina ${ }^{\mathrm{a}}$, Augustin Sadílek ${ }^{\mathrm{b}}$, Filip Hakl ${ }^{\mathrm{b}}$ \\ ${ }^{a}$ Mendelova univerzita v Brně, Lesnická a dřevařská fakulta

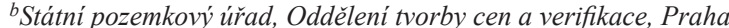

\begin{abstract}
Abstrakt
Při oceňování lesních majetků se tak jako při oceňování jiných majetků určuje cena zjištěná, obvyklá cena a tržní hodnota v závislosti na účelu ocenění. Les jako majetek je však považován za majetek se specifickými sociálními, ekologickými a ekonomickými atributy. Článek analyzuje praktické poznatky z aplikace ceny zjištěné, obvyklé ceny a tržní hodnoty. Pozornost je věnována nákladovému, porovnávacího a výnosového přístupu s ohledem na specifika lesních majetkủ. Příspěvek byl prezentován na konferenci ExFoS 2019 [17].
\end{abstract}

Klíčová slova: lesní majetek, obvyklá cena, zjištěná cena, tržní hodnota, nákladový př́istup, porovnávací přístup, výnosový př́stup.

\section{1. ÚVOD}

Při oceňování lesních majetků se určuje cena zjištěná, obvyklá cena a tržní hodnota $\mathrm{v}$ závislosti na účelu ocenění. $\mathrm{Z}$ tohoto hlediska se aplikují v zásadě stejné oceňovací metody a principy jako při oceňování jiných majetků. Obdobně jako při oceňování jiných majetků je při oceňování lesních majetků zaměňována obvyklá cena s tržní hodnotou, ačkoliv jde o rozdílné kategorie cen [1]. Lze se setkat i se záměnou obvyklé ceny s cenou určenou podle oceňovacího předpisu (cenou zjištěnou), což je podrobně analyzováno [2]. Na problémy spojené s koexistencí dvou oceňovacích systémů v ČR (administrativní a tržní) je upozorněno i jinými autory [3]. V kontextu oceňování majetku státu uvádí např́klad [4]: „Problematická cena obvyklá by se měla nahradit tržní hodnotou“. Problematikou tržního tržní ocenění lesů, včetně návrhu standardu tržního ocenění lesa se zabývá [5] [6].

Les je podmíněně obnovitelným přírodním zdrojem se specifickými sociálními a ekologickými atributy. To jednoznačně vynucuje modifikaci nákladového, porovnávacího a výnosového

\begin{abstract}
When valuating forestry assets, the determined value, the open market value, and the market value are found depending on the purpose of the valuation similarly to the valuation of other properties. As a property, however, a forest is considered to be an asset with specific social, environmental, and economic attributes. The article analyses practical findings from applications of the determined value, the open market value, and the market value. Furthermore, it focuses on the cost approach, the sales comparison approach, and the income approach while considering the specifics of forestry assets. The paper was presented at the ExFoS 2019 conference [17].
\end{abstract}

Keywords: forestry asset, open market value, determined value, market value, cost approach, comparison approach, income approach.

prrístupu pro potřeby oceňování lesních majetků. To se promítá do postupů oceňování lesních majetků cenou zjištěnou, cenou obvyklou a tržní hodnotou. V př́ispěvku analyzujeme tuto problematiku z dostupné literatury a znaleckých postupů. Cílem je najít srozumitelnou hranici pro rozlišení obvyklé ceny a tržní hodnoty lesních majetků a metod jejich určování. Př́ispěvek předkládáme i přesto, že by mnohé měl vyřešit nový zákon o oceňování majetku. Jeho přijetí je ale stále oddalováno. Článek může být oporou znalcům při praktické znalecké činnosti. S ohledem na fakt, že je určen také pro znalce, kteří nemají lesnické vzdělání a mají oprávnění k oceňování věcí nemovitých (tedy lesních majetků) jsou připomenuty alespoň okrajově některé lesnické pojmy.

\section{METODIKA}

Základním metodickým postupem je analýza různých definic cen v současné legislativě, analýza terminologie a konkrétních 
znaleckých postupů při určování ceny zjištěné, obvyklé ceny lesních majetků a tržní hodnoty lesních majetků. Pozornost je věnována analýze modifikací nákladového, porovnávacího a výnosového prrístupu s ohledem na specifika lesních majetků.

\section{DEFINICE, TERMINOLOGIE, LEGISLATIVA}

\subsection{Lesní majetek}

Za lesní majetek považujeme $\mathrm{v}$ tomto příspěvku soubor věcí nemovitých, konkrétně lesních pozemků s lesními porosty.

\section{Les}

Lesem se podle zákona č. 289/1995 Sb., o lesích, ve znění pozdějších predeisů, rozumí lesní porosty s jejich prostředím a pozemky určené k plnění funkcí lesa [7].

Lesní majetek a les chápeme pro účely tohoto př́spěvku jako synonymum, a to $\mathrm{z}$ důvodu zjednodušení problematiky.

\section{Lesnická typologie}

Lesnická typologie, jako základní disciplína hospodářské úpravy lesů, se zabývá klasifikací trvalých ekologických podmínek. Lesnická typologie rozděluje lesy na segmenty s podobnými růstovými podmínkami, vyhodnocuje tyto podmínky, a vyvozuje závěry pro vhodné lesnické hospodaření. Lesnická typologie poskytuje mimo jiné podklady pro oceňování lesních pozemků podle § 12 zákona č. 151/1997 Sb., o oceňování majetku, v platném znění [8]. Pro oceňování je klíčová diferenciace typologických jednotek tzv. souborů lesních typů (SLT) podle jejich potenciální úrodnosti (produkce).

\section{Oceňování lesního majetku}

Systematická činnost vedoucí k určení ceny lesního majetku, souboru specifických věcí nemovitých, konkrétně lesních pozemků a porostů, pro různé účely.

\section{Cena}

Pojem cena je používán pro požadovanou, nabízenou nebo skutečně zaplacenou částku za zboží nebo službu (věc nemovitou). Může nebo nemusí mít vztah $\mathrm{k}$ hodnotě, kterou věci přisuzují jiné osoby [9].

\section{Hodnota}

Hodnota není skutečně zaplacenou, požadovanou nebo nabízenou cenou. Je to ekonomická kategorie, vyjadřující peněžní vztah mezi věcí nemovitou, kterou lze koupit na straně jedné a kupujícími a prodávajícím na straně druhé. Při určení hodnoty se jedná o odhad. Hodnota vyjadřuje užitek, prospěch vlastníka věci nemovité $\mathrm{k}$ datu, $\mathrm{k}$ němuž se odhad hodnoty provádí. Existuje řada hodnot podle toho, jak jsou definovány, jaké vlastnosti věci vyjadřují (např. věcná hodnota, tržní hodnota, výnosová hodnota apod.), přitom každá z nich může být vyjádřena zcela jiným číslem. Při oceňování je proto vždy třeba přesně definovat, jaká hodnota je zjišt'ována [9].

\section{Tři př́ístupy (principy, způsoby) k určování hodnoty a ceny}

Obecně je znaleckou teorií a praxí $\mathrm{v}$ různých modifikacích aplikován model tří přístupů (principů, způsobů) při určování hodnoty a ceny. Následně jsme základní oceňovací model [10] přizpůsobili pro účely oceňování lesa:

\section{- Nákladový př́stup}

Hledaná hodnota je indikována (naznačena) náklady vynaloženými na zalesnění pozemku a pěstováním vzniklého lesa, se zohledněním jejich stavu. Výsledkem je nákladová (věcná, substanční) hodnota lesních pozemků a porostů, lesa, případně lesního majetku.

\section{- Porovnávací př́ístup}

Hledaná hodnota je indikována (naznačena) cenami obdobných lesů, lesních majetků, lesních pozemků a porostů dosahovanými na současném trhu.

\section{- Výnosový přístup}

Hledaná hodnota je indikována (naznačena) prospěchem (užitkem), který z vlastnictví lesa, lesního majetku, lesních pozemků a porostů vyplývá. Výnosovou hodnotou lesa rozumíme zjednodušeně řečeno jistinu, kterou je nutno při stanovené úrokové sazbě (úrokové míře) uložit, aby úroky z této jistiny byly stejné jako čistý výnos z lesa.

\section{Náklady a výnosy lesního majetku}

$\mathrm{V}$ rámci nákladového a výnosového př́stupu je nutné určit konkrétní výši nákladů a výnosů. Při oceňování lesních majetků lze použít podkladů z účetní evidence (pokud existuje a je k dispozici). Širší využití pro potřeby oceňování mají modelové kalkulace, které používají specifického členění nákladů a výnosů ve vazbě na prováděné lesnické činnosti. U majetků malých výměr není zpravidla jiná možnost než modelová kalkulace nákladů a výnosů. Dále uvádíme základní systematizaci nákladů a výnosů pro účely oceňování lesních majetků.

Pokud v tomto článku hovoříme o nákladovém přístupu, kterým lze určit nákladovou hodnotu lesního porostu do věku, kdy začne porost přinášet výnosy, máme tím na mysli náklady na vznik lesního porostu zalesněním (náklady na zalesnění) a následnou péči a až po zajištění, náklady na další výchovu (bez výnosů) a ochranu včetně správních nákladů.

Samostatně jsou v modelech kalkulovány tzv. kulturní náklady též náklady na zjišsěnou kulturu, které vyjadřují náklady vynaložené na vznik lesního porostu zalesněním a následnou péči od doby založení do doby tzv. zajištění. O vzniklý mladý lesní porost (lesní kulturu) je nutné se starat a chránit ji před útlakem buřeně (název pro nežádoucí vegetaci škodící zalesněnému prostu), poškození hmyzem, poškození zvěríi. Cílem těchto nákladových činností je dosáhnout tzv. zajištění lesní kultury, která je charakterizována tím, že na ploše se vyskytuje požadovaný počet jedinců odpovídající dřeviny v požadovaném rozmístění, stromky vykazují trvalý výškový přírůst, jsou odrostlé negativnímu vlivu buřeně a nejsou výrazně poškozeny [18].

Pokud v tomto článku hovoříme o výnosovém přístupu, máme již na mysli určování výnosů z tržeb za vytěžené a prodané dříví po odečtení nákladů na těžbu dříví, nákladů na zajištěnou kulturu a nákladů správních. Do správních nákladů se zahrnují kromě režie, daní, poplatků také náklady vynakládané v období po zajištění lesního porostu a další náklady jako je ochrana lesa, údržba cest apod. Těžebními náklady se rozumí náklady na těžbu (sklizeň), kam patří kácení, odvětvení, sortimentace a doprava na odvozní místo. Výnos je v oceňovacích modelech představován jako tzv. hodnota mýtní výtěže. Stanoví se tak, že od tržeb za prodané dříví se odečtou těžební náklady.

Výše uvedené př́stupy oceňování jsou přehledně uvedeny v tab. 1. 
Tab. 1 Oceňovací prístupy.

Tab. 1 Valuation approaches.

\begin{tabular}{|c|c|c|}
\hline \multicolumn{3}{|c|}{ OCEŇOVACÍ PŘÍSTUPY } \\
\hline Nákladový & Porovnávací & Výnosový \\
\hline \multicolumn{3}{|c|}{ Hodnota lesního majetku je indikována } \\
\hline Náklady na zalesnění a pěstování lesa & $\begin{array}{l}\text { Cenami obdobných lesních majetků } \\
\text { dosahovaných na aktuálním trhu }\end{array}$ & $\begin{array}{l}\text { Prospěchem (užitkem) který z vlastnictví } \\
\text { lesního majetku vyplývá }\end{array}$ \\
\hline \multicolumn{3}{|c|}{ Které úkoly je třeba řešit } \\
\hline Kalkulovat kulturní a ostatní náklady & $\begin{array}{l}\text { Hledat vhodné referenční cenové vzorky } \\
\text { Adjustovat vzorky } \\
\text { Provádět korekce vzorků dle logiky horší - } \\
\text { lepší oproti oceňovanému lesnímu majetku } \\
\text { Statistické zpracování }\end{array}$ & $\begin{array}{l}\text { Konkretizovat budoucí prospěch } \\
\text { v podobě výnosů a nákladů lesního } \\
\text { majetku, transformovat prospěch } \\
\text { k současnosti } \\
\text { Kvalitativní analýza a kvantifikace } \\
\text { Úroková míra v lesnictví }\end{array}$ \\
\hline \multicolumn{3}{|c|}{ Výsledek } \\
\hline \multirow[t]{2}{*}{ Nákladová hodnota } & $\begin{array}{c}\text { Porovnávací hodnota } \\
\text { Obvyklá cena } \\
\text { podle } \S 2 \text { ZOM. } \\
\text { Pouze porovnáním již realizovaných prodejů }\end{array}$ & Výnosová hodnota \\
\hline & $\begin{array}{l}\text { Odhad finální tržní hodnoty lesního majetk } \\
\text { (lesního pozemku s lesním porostem) } \\
\text { Rekonciliace indikovaných hodnot }\end{array}$ & \\
\hline \multicolumn{3}{|c|}{ Tržní hodnota } \\
\hline
\end{tabular}

\section{Cena zjištěná}

Pro přesně specifikované účely, především pro účely daňové zjištění základu daně existuje tzv. oceňovací předpis:

Zákon č. 151/1997 Sb., o oceňování majetku, ve znění pozdějších předpisů (ZOM) [8] a jeho prováděcí vyhláška č. 441/2013 Sb. (OV) v aktuálním znění [11]. Podle $\S 2$ odst. 3 ZOM je cena určená podle tohoto zákona jinak než obvyklá cena nebo mimořádná cena cenou zjištěnou. Cena oceňované věci je prriřazena v OV stanoveným postupem podle konkrétních cen přiřazených stavbám, jednotkám, pozemkům, věcem.

Cena zjištěná je termín uváděný v ZOM.

Historicky se ve znalecké praxi používalo rovněž termínů cena podle cenového předpisu, cena vyhlášková, cena úřední, cena administrativní. Proto se lze setkat s označováním a ztotožněním:

Cena zjištěná $=$ podle cenového predpisu $=$ vyhlášková $=$ $=$ administrativni ${ }^{=}$úredni.

\section{Obvyklá cena}

Obvyklá cena je v českém právním řádu definovaná vícekrát. Z hlediska oceňování lesa jako majetku, př́padně lesních porostů a lesních pozemků je diskutovaným a problematickým úkonem určování obvyklé ceny splňující definici obvyklé ceny podle $\S 2$ odst. 1 ZOM:

„Obvyklou cenou se pro účely tohoto zákona rozumí cena, která by byla dosažena při prodejích stejného, popřípadě obdobného majetku nebo při poskytování stejné nebo obdobné služby v obvyklém obchodním styku v tuzemsku ke dni ocenění. Přitom se zvažují všechny okolnosti, které mají na cenu vliv, avšak do její výše se nepromítají vlivy mimořádných okolností trhu, osobních poměrů prodávajícího nebo kupujícího ani vliv zvláštní obliby. Mimořádnými okolnostmi trhu se rozumějí např́ílad stav tísně prodávajícího nebo kupujícího, důsledky přírodních či jiných kalamit. Osobními poměry se rozumějí zejména vztahy majetkové, rodinné nebo jiné osobní vztahy mezi prodávajícím a kupujícím. Zvláštní oblibou se rozumí zvláštní hodnota přikládaná majetku nebo službě vyplývající z osobního vztahu k nim. Obvyklá cena vyjadřuje hodnotu věci a určí se porovnáním.“

\section{Tržní hodnota a obvyklá cena}

Tržní hodnota není v českém právním řádu definována. Používá se definice převzatá $\mathrm{z}$ definic podle Mezinárodních oceňovacích standardů (ISV) [12], Evropských oceňovacích standardů (EVS) a profesionálních standardů (RICS):

„Tržní hodnota je odhadnutá částka, za kterou by bylo možné k datu ocenění posuzovaný majetek směnit mezi ochotným kupujícím a ochotným prodávajícím $\mathrm{v}$ nezávislé transakci a po uskutečnění náležitého marketingu, přičemž každá ze stran jedná informovaně, obezřetně a bez donucení.“

Takto definovaná tržní hodnota bývá někdy vnímána i jako cena obvyklá, jak je definována v $§ 2$ odst. 1. ZOM.

Dle [2] současná česká legislativa pojem tržní hodnota nezná, někteří odborníci však tvrdí, že v ČR je jejím synonymem obvyklá cena, jejíž definice je uvedena v ZOM.

Obvyklá cena a tržní hodnota jsou ale dle komentáře Ministerstva financí $\mathrm{k}$ ceně obvyklé [1] považovány za rozdílné kategorie hodnoty: 
Tab. 2 Přehledný rámec systému cen v ČR podle cenového práva k roku 2015 [9].

Tab. 2 The Framework of the price system in the Czech Republic in accordance with the price law of the year 2015 [9].

\begin{tabular}{|c|c|c|c|}
\hline \multirow{2}{*}{$\begin{array}{l}\text { Zákon č. } 89 / 2012 \\
\text { Sb., občanský } \\
\text { zákoník }\end{array}$} & $\begin{array}{l}\text { Cena obvyklá } \\
(\S 492 / 1)\end{array}$ & \multicolumn{2}{|l|}{ Hodnota věci vyjádřená v penězích } \\
\hline & $\begin{array}{l}\text { Cena mimořádná } \\
(\S 492 / 2)\end{array}$ & \multicolumn{2}{|c|}{$\begin{array}{l}\text { Hodnota s přihlédnutím ke zvláštním poměrům nebo ke zvláštní oblibě } \\
\text { vyvolané náhodnými vlastnostmi věci }\end{array}$} \\
\hline \multirow{8}{*}{$\begin{array}{l}\text { Zákon č. } 526 / 1990 \\
\text { Sb., o cenách (ZOC) }\end{array}$} & \multirow{5}{*}{$\begin{array}{l}\text { Ceny sjednané (smluvní) } \\
\S 2 \text { odst. } 1 \text { písm. a) }\end{array}$} & volné & $\begin{array}{l}\text { Cena obvyklá } \\
\text { (§ } 2 \text { odst. } 6 \text { ZOC) }\end{array}$ \\
\hline & & \multirow{4}{*}{$\begin{array}{l}\text { regulované } \\
\text { seznam regulovaných cen se } \\
\text { zveřejňuje v cenovém věstníku }\end{array}$} & -úředně (§5) \\
\hline & & & -věcně $(\$ 6)$ \\
\hline & & & - ěasově $(\S 8)$ zrušeno) \\
\hline & & & -cenovým moratoriem $(\S 9)$ \\
\hline & \multirow{3}{*}{$\begin{array}{l}\text { Ceny určené podle } \\
\text { zvláštního předpisu } \\
-\S 2 \text { odst. } 1 \text { písm. b) }\end{array}$} & \multirow{3}{*}{$\begin{array}{l}\text { Zákon } \\
\text { č. 151/1997 Sb., } \\
\text { o oceňování majetku } \\
\text { (ZOM) } \\
\text { Prováděcí oceňovací vyhláška č. } \\
\text { 441/2013 Sb. } \\
(\mathrm{OV})\end{array}$} & $\begin{array}{l}\text { Obvyklá cena } \\
\text { ( } \$ 2 \text { odst. } 1 \text { ZOM })\end{array}$ \\
\hline & & & $\begin{array}{l}\text { Cena mimořádná } \\
(\S 2 \text { odst. } 2 \text { ZOM })\end{array}$ \\
\hline & & & $\begin{array}{l}\text { Cena zjištěná } \\
\text { ( } \$ 2 \text { odst. } 3 \text { ZOM) }\end{array}$ \\
\hline
\end{tabular}

„Cena obvyklá: Viz ustanovení § 2 odst. 1 ZOM [8]. Statistické vyhodnocení již realizovaných prodejů. Cena obvyklá se určuje porovnáním s již realizovanými historickými cenami, do kterých se však nemohou promítnout zvláštní vlivy. Obvyklá cena vyjadřuje hodnotu věci a určí se porovnáním.

Tržní hodnota je často zaměňována za obvyklou cenu. Rozdíl oproti obvyklé ceně je v odhadu realizovatelné ceny na trhu za nabízený majetek (odhad do budoucnosti). Tržní hodnotu lze spočítat na rozdíl od obvyklé ceny vyhodnocením věcné hodnoty (nákladové ocenění), výnosové hodnoty a ceny určené porovnáním s cenami obvyklých věcí (nemovitostí).“

ČKOM (Česká komora odhadců majetku) ve svých metodikách uvádí [13]:

„Tržní hodnota podle definice ISV, EVS, RICS a cena obvyklá dle $§ 2$ zákona ZOM jsou dvě rozdílné kategorie hodnoty.“

\section{Porovnávací metoda}

Porovnávací hodnota lesního majetku se určuje porovnáním s cenami lesních majetků podobných, které byly dosaženy při jejich prodeji porovnání s porovnatelnými cenovými vzorky, které mohou reprezentovat oceňovaný lesní majetek. V zásadě lze použít přímé a nepřímé porovnání.

\section{Př́ímé porovnání}

Metoda př́mého porovnání určuje porovnávací hodnotu lesa př́mým porovnáním s porovnatelnými cenovými vzorky konkrétních realizovaných prodejů lesa se známou cenou. Odlišnost cenových vzorků od lesa oceňovaného se vyjadřuje koeficienty odlišnosti vzájemným porovnáním na principu horší a lepší.

\section{Nepřímé porovnání}

Metoda neprrímého porovnání určuje porovnávací hodnotu porovnáním s cenovým referenčním vzorkem, který reprezentuje (zastupuje) výběrový soubor vzorků se známou cenou a vlastnostmi, charakteristikami souboru vzorků (tab. 2).

\section{SPECIFIKA URČOVÁNÍ CENY ZJIŠTĚNÉ LESNÍHO MAJETKU}

Cena zjištěná lesního majetku patří do skupiny cen, které se určují podle oceňovacího předpisu, konkrétně podle zákona č. 151/1997 Sb., o oceňování majetku (ZOM), a jeho prováděcí vyhlášky č. 441/2013 Sb. (OV), v aktuálním znění.

Lesy patří k jedinému př́rodnímu zdroji, který je možné ocenit podle ZOM a OV. V § 1 odst. 2 ZOM je uvedeno: „Zákon se nevztahuje na sjednávání cen a neplatí pro oceňování přírodních zdrojů kromě lesů.“

\section{Oceňování lesních pozemků}

Pro účely oceňování jsou lesní pozemky definovány v § 9 ZOM jako pozemky evidované $v$ katastru nemovitosti jako druh „lesní pozemky“ a zalesněné nelesní pozemky ( 99 ZOM). Druh pozemku „lesní pozemek“ je pozemek určený k plnění funkcí lesa podle zákona o lesích. Lesní pozemek se oceňuje výnosovým a porovnávacím způsobem podle plošně převládajícího souboru lesních typů (§ 12 ZOM).

Zajímavá je historie odvození cen lesních pozemků [14]: „Ceny lesních pozemků byly zpracovány na bázi tzv. potenciální produkce. Výnosové výpočty nebyly prováděny za účelem získání cen lesních pozemků, ale za účelem diferenciace typologických jednotek, tzv. souborů lesních typů (SLT) podle jejich potenciální úrodnosti (produkce). Kritériem diferenciace cen lesních pozemků se stala průměrná roční renta z lesa kalkulovaná pro jednotlivé SLT. Mezním hodnotám byla přiřazena minimální a maximální cena lesního pozemku ve vazbě na ceny zemědělských pozemků. Uvnitř intervalu byly ceny určeny proporcionálně podle kalkulované renty. Výsledkem byla tabulka od nejlepších po nejhorší SLT. Politickým rozhodnutím pak bylo stanoveno rozpětí cen lesních pozemků od $0,24 \mathrm{Kč} / \mathrm{m}^{2}$ po $6,60 \mathrm{Kč} / \mathrm{m}^{2}$. Maximální cena lesního pozemku mohla dosahovat maximálně poloviny nejvyšší ceny zemědělských pozemků. Od roku 2003 bylo rozpětí upraveno 
od $0,70 \mathrm{Kč} / \mathrm{m}^{2}$ do $7,50 \mathrm{Kč} / \mathrm{m}^{2}$. V současnosti činí rozpětí od 1,15 $\mathrm{Kč} / \mathrm{m}^{2}$ do $10,16 \mathrm{Kč} / \mathrm{m}^{2}$.“

Proto je v ZOM uvedeno, že lesní pozemek se oceňuje výnosovým a porovnávacím způsobem.

\section{Oceňování lesních porostů}

Pro účely oceňování jsou lesní porosty definovány v § 14 ZOM odkazem na § 2 písm. c) zákona č. 289/1995 Sb., o lesích.

Lesní porost se oceňuje nákladovým a výnosovým způsobem (§ $15 \mathrm{ZOM})$.

\section{§ 40 Lesní porost na lesním a nelesním pozemku}

Poměrně rozsáhlý $§ 40$ a na něj navazující další $\S \S 41$ a 42 . Základní ceny lze upravit. Není výslovně uvedeno, k jakému účelu je ocenění podle $\S 40$ určeno. S ohledem na existenci zjednodušeného způsobu pro účely daně z nabytí věci nemovité podle $\S 45$ lze mít za to, že má být využíván pro jiné než daňové účely. Ačkoliv to není v textu $\S 40$ uvedeno, lze předpokládat, že aplikace tohoto ocenění je vhodná především pro určení majetkové újmy na lesním majetku a pro př́pady určování ceny obvyklé za oceňovací situace, kdy nelze určit cenu obvyklou porovnáním, a má se proto určit cena zjištěná.

Určování ceny porostu podle $\S 40$ není jednoduchou záležitostí. To lze doložit např́íklad faktem, že cca $80 \%$ až $90 \%$ účastníků kurzů oceňování lesa má při zpracování cvičných př́ikladů potíže. Komplikovanost $\S 40$ souvisí s již zmíněným způsobem ocenění lesních porostů nákladovým a výnosovým způsobem. Rozsah př́spěvku neumožňuje podrobně osvětlit postup tvůrců vyhlášky. $\mathrm{S}$ velkou mírou zjednodušení však lze pro pochopení podstaty uvést alespoň nejdůležitější. Je známý fakt, že hodnota lesního porostu roste s jeho věkem (za jinak stejných podmínek (dřevina, bonitní stupeň, poměr výnosů a nákladů). Nákladová hodnota lesního porostu se tak odvíjí od nákladů vynaložených na zalesnění lesního pozemku a na následnou péči o založený lesní porost. Cílem vynaložených nákladů je dosažení užitku, to je výnosů ze sklizně lesního porostu (těžby dřiví). Vynaložené náklady s časem rostou, nákladová hodnota lesního porostu v čase roste. Od určitého věku porostu je možné získávat užitky z lesního porostu v podobě tržeb za sklizené dříví (těžby dříví), to je spojeno s náklady vynaloženými na sklizeň (těžbu dřiví). Od určitého věku má lesní porost také výnosovou hodnotu, která je výslednicí rozdílu mezi náklady vynaloženými na zalesnění porostu a na následnou péči a výnosy z tržeb za sklizené (vytěžené) dříví po odečtení nákladů na sklizeň (těžbu). OV objektivní fakt vývoje nákladové hodnoty a výnosové hodnoty porostu $\mathrm{v}$ čase respektuje tím, že hodnotu lesního porostu různého věku počítá různými metodami, a to nákladovým a výnosovým způsobem.

Ve věku cca do 30 až 40 let je aplikována nákladová hodnota porostu.

Od věku cca 30 až 40 let až do věku, kdy porost dosahuje tzv. mýtního věku, je aplikována tzv. očekáváná hodnota lesního porostu. Jde o období, kdy je ocenění lesního porostu na pomezí mezi nákladovou hodnotou a výnosovou hodnotou. Lesní porost již začíná poskytovat výnosy, jde však o výnosy spojené s tzv. těžbou předmýtní. Primárním cílem není výnos z těžby, ale zvýšení budoucí výnosové hodnoty lesních porostů (proto očekávaná hodnota).

Ve věku, kdy porosty dosahují tzv. mýtního věku, to je cca 20 let před obmýtím (u) je aplikována výnosová hodnota lesního porostu.

\section{§ 45 Oceňování lesního porostu zjednodušeným způsobem}

Pro účely daně z nabytí nemovitých věcí se cena lesního porostu určí zjednodušeným způsobem. Zjednodušení spočívá v tom, že 13 skupin dřevin je nahrazeno 6 skupinami dřevin, místo věkových stupňů (interval 10 let) jsou užívány věkové třídy (interval 20 let) a je použito pouze maximální obmýtí pro dané skupiny dřevin. Neuplatňují se žádné úpravy srážkami nebo přirážkami.

$\mathrm{V}$ současnosti je častým př́padem prodej lesního pozemku s lesním porostem s výskytem souší až $100 \%$, pritom tabulkové sazby počítají s ojedinělým výskytem souší. Míra zdanění je $\mathrm{v}$ těchto př́ípadech neadekvátní. Řešením by bylo umožnění srážky.

\section{Oceňování lesních pozemků}

S určování ceny pozemků podle $\S 7 \mathrm{OV}$ nejsou zpravidla žádné problémy. Základní cenu lze upravit.

\section{Poznámky k praktické aplikaci OV při určování zjištěné ceny lesních majetků}

Následující poznámky vznikly v průběhu konzultací lektorů a účastníků kurzu oceňování lesa, které jsou pravidelně organizovány na Lesnické a dřevařské fakultě Mendelovy univerzity.

\section{Stanovení věku porostu (dřeviny)}

Věk porostu (dřeviny) ke dni ocenění určujeme z LHP/LHO. K věku uvedenému V LHP/LHO připočítáváme každý následující rok po počátku platnosti LHP/LHO (rok počátku platnosti nezapočítáváme) včetně roku, ve kterém oceňujeme.

Příklad: platnost LHP/LHO je od 1. 1. 2015 a oceňujeme k roku 2018. Tedy připočítáme 3 roky (rok 2015 je jediný rok, kdy jsou údaje LHP/LHO aktuální, přesněji 1. 1. 2015).

\section{Stanovení relativní bonity lesního porostu (dřeviny)}

Dle textové poznámky pod převodní tabulkou v př́loze č. 29. je uvedeno, že je třeba provést prrepočet relativních bonit (nelze použít relativní bonity př́mo z LHP/LHO). V případě rozdílů mezi relativní bonitou uvedenou $\mathrm{v}$ LHP/LHO a výsledkem převodu podle převodní tabulky $\mathrm{v}$ př́loze č. 29 , má přednost výsledek z převodní tabulky.

\section{$\S 40$}

Hodnoty mýtní výtěže $\left(\mathrm{A}_{\mathrm{u}}\right)$, náklady na zajištěnou kulturu (c), věkové hodnotové faktory $\left(\mathrm{f}_{\mathrm{a}}\right)$, opravný faktor pro obmýtí (1/ $\mathrm{f}_{\mathrm{uv}}$ ) či věkový koeficient lesního porostu $\left(\mathrm{K}_{\mathrm{v}}\right)$ se vztahují vždy ke konkrétní dřevině v porostní skupině. Každou dřevinu v rámci porostní skupiny je tedy třeba posuzovat samostatně. Každá dřevina v rámci porostní skupiny může mít jiné hodnoty uvedené výše, prrípadně se může počítat podle jiné varianty vzorce uvedeného v $\$ 40$ odst. 2 oceňovací vyhlášky. Rozhodující pro ocenění je skutečný (aktuální) věk dřeviny. Pokud tento skutečný věk dřeviny překročí obmýtí uvedené v LHP/LHO, je třeba ještě otestovat, zda se skutečný věk dřeviny nachází uvnitř či mimo rozpětí obmýtí dané dřeviny stanovené ve vyhlášce (pozn.: toto rozpětí je možné zjistit např. v prŕloze č. 28,30 nebo 32 ). Pak se bud' interpoluje v rámci tohoto rozpětí obmýtí, nebo se použijí hodnoty pro nejnižší či nejvyšší obmýtí dané dřeviny, jak stanovuje postup uvedený v $\S$ 40 odst. 5 . 


\section{$\S 40$ odst. 2}

Zde uvedený vzorec pro výpočet základní ceny jednotlivých skupin dřevin použijeme pouze $\mathrm{v}$ prrípadech, kdy skutečný věk dřeviny je nižší nebo roven obmýtí uvedenému v LHP/LHO a obmýtí z LHP pro danou dřevinu má tabulkové hodnoty v př́loze č. 32 oceňovací vyhlášky.

$\S 40$ odst. 8

V případech, kdy skutečný věk dřeviny je nižší, nebo roven obmýtí uvedenému v LHP/LHO a obmýtí z LHP pro danou dřevinu nemá tabulkové hodnoty $\mathrm{v}$ př́loze č. 32 oceňovací vyhlášky, avšak nachází se $\mathrm{v}$ rozpětí obmýtí přiřazeného jednotlivým skupinám dřevin v př́loze č. 28 oceňovací vyhlášky, použije se varianta vzorce podle $\S 40$ odst. 4 oceňovací vyhlášky. To znamená, že v takových př́padech je nutné do základní ceny skupiny dřevin zavést ještě tzv. opravný faktor $1 / f_{u v}$. Tato situace nastane např́klad u dřeviny SM s obmýtím podle LHP/LHO 90 let. Č́́selnou hodnotu „f“ do zlomku $1 / \mathrm{f}_{\text {uv }}$ budeme hledat v nejbližším vyšším obmýtí podle přílohy č. 32 oceňovací vyhlášky, tzn. v tabulce pro obmýtí 100 let. Vzhledem k tomu, že je obmýtí podle LHP 90 let, budeme tuto hodnotu hledat v řádku 81 - 90 let. Věkový hodnotový faktor fa najdeme ve stejné tabulce podle aktuálního věku dřeviny (aktuální věk dřeviny může být např́klad a = 42 let). Hodnota mýtní výtěže $\mathrm{A}_{\mathrm{u}}$ pro obmýtí 90 let není $\mathrm{v}$ tabulkách, a proto se musí určit interpolací z př́lohy č. $30, \mathrm{tj}$. z hodnot mýtní výtěže mezi obmýtím 80 a 100 let.

\section{$\S 40$ odst. 5}

Tuto variantu vzorce použijeme v př́ípadech, kdy skutečný věk dřeviny v rámci porostní skupiny překračuje mezní hodnoty obmýtí pro danou skupinu dřevin z prílohy č. 30 oceňovací vyhlášky. Hodnotu mýtní výtěže v obmýtí „u“ (používá se symbolu $\mathrm{A}_{\mathrm{u}}$ ) však musíme odečíst z maximálního obmýtí z přílohy č. 30 dané skupiny dřevin, nikoliv z hodnoty obmýtí z LHP/LHO!

\section{$\S 40$ odst. 6}

Tuto variantu vzorce použijeme $v$ případech, kdy skutečný věk dřreviny $\mathrm{v}$ rámci porostní skupiny je vyšší, než obmýtí stanovené v LHP/LHO a zároveň se skutečný věk dřeviny nachází $\mathrm{v}$ rámci rozpětí obmýtí přiřazeného skupinám dřevin $\mathrm{v}$ př́loze č. 30 oceňovací vyhlášky. Jedná se o interpolaci pro věk a mezi tabulkovými hodnotami mýtní výtěže, a proto se používá symbolu Aa.

\section{Věkový koeficient $K_{\mathbf{v}}$}

Věkový koeficient $\mathrm{K}_{\mathrm{v}}$ počítáme jen $\mathrm{v}$ případech, $\mathrm{kdy}$ je věk dřeviny nižší než její obmýtí, a to podle $\S 42$ odst. 2 oceňovací vyhlášky.

Ale v případech, kdy je v LHP pro danou porostní skupinu stanoveno obmýtí např. $u=100$ let a skutečný věk dřevin je např. $\mathrm{a}=110$ let, rozhoduje při výpočtu $\mathrm{K}_{\mathrm{v}}$ rozmezí obmýtí stanovené pro jednotlivé skupiny dřevin $\mathrm{v}$ př́loze č. 28 oceňovací vyhlášky s tím, že se při překročení limitních obmýtí pro dané skupiny dřevin uvedené ve vyhlášce musí použít ustanovení o nejnižším a nejvyšším obmýtí ( $\$ 40$ odst. 5). Například dřevina DB má stanovené minimální obmýtí $\mathrm{u}=120$ let. Proto pro DB budeme $\mathrm{K}_{\mathrm{v}}$ ve vzorci počítat tak, že $\mathrm{u}=120 \mathrm{a} \mathrm{a}=110$, ale pro SM nikoliv.

\section{SPECIFIKA URČOVÁNÍ OBVYKLÉ CENY A TRŽNÍ HODNOTY LESNÍCH MAJETKŮ}

Vycházíme z výše uvedeného faktu, že obvyklá cena a tržní hodnota lesních majetků jsou rozdílné kategorie cen (hodnot), které však lze zahrnout pod společný pojem tržní oceňování lesních majetků, který je v posledních letech používán [14].

Při určování výsledné hodnoty a ceny se v rámci tržního oceňování aplikují nákladový, porovnávací a výnosový př́istup (viz tab. 1). Také OV využívá tyto tři přístupy. Na rozdíl od OV se v rámci těchto př́stupů využívají data vzniklá na základě chování účastníků trhu. Předpokladem, aby se mohlo tržní ocenění aplikovat je, že se lesní majetky prodávají a kupují (př́istup porovnávací), př́ípadně propachtovávají (výnos z pachtu), je nutné znát konkrétní výnosy z prodeje produkce lesní výroby (těžby dříví), př́ípadně jiných produktů a užitků z oceňovaného lesního majetku a náklady vynaložené na dosažení výnosů (přístup výnosový). Znalost tržních nákladů na jednotlivé činnosti lesní výroby od zalesnění, zajištění a péče o vzniklé porosty až po sklizeň (těžbu dříví), které se používají u výnosového prrístupu se podle situace a účelu také využívají u nákladového přístupu.

\section{Přístup porovnávací}

Při tržním oceňování je považován za hlavní pilíŕ, to souvisí s tím, že se dá použít téměř vždy a lze jím určit jak cenu obvyklou, tak tržní hodnotu. Objasnili jsme, že za obvyklou cenu lesního majetku lze považovat pouze cenu určenou na základě porovnávací hodnoty. Porovnávat lze výhradně s cenovými vzorky reprezentovaných realizovanými prodeji srovnatelných majetků v blízké minulosti. Stěžejní je, že od roku 2014 Český úřad zeměměřický a katastrální zpřístupnil cenové údaje a listiny kupních smluv, což odstranilo do té doby obtížné získávání údajů o realizovaných prodejích. Klíčová je existence realizovaných obchodů, které jsou současně vhodné pro porovnání. To znamená, že referenční cenové vzorky použité pro porovnání by měly být co nejvíce podobné lesnímu majetku oceňovanému. Rozdílnost cenových vzorků a oceňovaného majetku by měla být zohledněna koeficienty odlišnosti. Je přitom zcela zjevné, že koeficienty odlišnosti při oceňování lesních majetků porovnávací hodnotou se budou vždy obtížně hledat. Patrně bude často překračováno praxí uznávané omezení úpravy cenových vzorků v rozmezí cca $\pm 20 \%$. Zkušenosti znalce, rozsah analýzy trhu s lesními majetky a rozsah disponibilní databáze prodejů jsou přitom zásadní. Jen velmi těžko lze najít hranici mezi odůvodněným a neodůvodněným konstatováním znalce, že se nepodařilo zajistit dostatečný počet relevantních cenových vzorků pro určení ceny obvyklé, případně pro stanovení tržní hodnoty.

\section{Přístup výnosový}

Při tržním oceňování lesních majetků je výnosový přístup založen na úvaze, že hodnota lesního majetku je dána součtem diskontovaných čistých výnosů, které plynou jeho majiteli $\mathrm{v}$ budoucnosti.

Metoda je uplatnitelná pro majetky větších výměr při vyrovnané věkové struktuře a stabilním a rovnoměrném výnosu v kalkulačním období. Jde o majetky větších výměr, přitom je empirická zkušenost, že jde o majetky od výměry cca 200 až 250 ha př́ípadně majetky 
menších výměr, ovšem za předpokladu optimální věkové struktury, těžební trvalosti a nepřetržitosti. Problematika určování nákladů a výnosů při výnosovém oceňování lesních majetků je v lesnictví předmětem tzv. nákladových a výnosových modelů. Komplexněji je problematika řešena např́ílad v rámci výzkumného projektu Grantové služby LČR s názvem „Diferenciální lesní renta“ [15].

Důležitým parametrem výnosového př́stupu je úroková míra. Tu lze vyjádřit jako poměr očekávaného čistého ročního výnosu plynoucích z majetku a ceny majetku dosažené prri jeho prodeji.

Úrokové míře v lesnictví je věnována samostatná monografie [16].

Výnosovou hodnotu lesního majetku lze určovat výpočty. V literatuře [14] [16] jsou uváděny různé doporučené varianty výnosových výpočtů. Aplikují se v zásadě varianty kalkulace periodických výnosů s různými periodami až po nejznámější výnosový vzorec s nekonečnou roční věcnou rentou:

$$
\mathrm{VH}=\frac{\mathrm{R}}{\mathrm{p}} \times 100 \mathrm{v} \mathrm{Kc} / \mathrm{ha},
$$

kde:

VH výnosová hodnota lesního majetku,

$\mathrm{R} \quad$ roční renta $\mathrm{v} \mathrm{Kč} / \mathrm{ha}$ (trvale odnímatelný zisk)

z oceňovaného lesního majetku,

$\mathrm{p} \quad$ míra kapitalizace $\mathrm{v} \%$.

\section{Přístup nákladový}

Při tržním ocenění lesních majetků je tento př́istup uplatnitelný pro určení nákladové hodnoty lesních porostů, to je nákladů vynaložených na zalesnění a následnou péči o porost. Př́istup je omezený pro ocenění mladých lesních porostů. Např́iklad pro účely vyvlastnění lesních pozemků s mladými porosty, př́ípadně pro účely odškodnění v př́ípadě vzniku škod na lesních porostech. Nutno si také uvědomit, že nákladový přístup při oceňování lesního porostu není z hlediska účelu totéž jako kalkulace nákladů činností lesní výroby, která se používá $\mathrm{v}$ rámci výnosového přístupu při oceňování lesa.

\section{ZÁVĚR}

\section{Cena zjištěná}

Pokud je zadavatelem požadováno ocenění lesního majetku cenou zjištěnou pro účely daně z nabytí věci nemovité, ocení se lesní majetek takto:

\section{Cena lesního pozemku podle $§ 7 \mathrm{OV}$ $+$ \\ Cena lesního porostu podle $\S 45 \mathrm{OV}$ $=$}

Zjištěná cena lesního majetku pro účely daně z nabytí věci nemovité

Pokud je zadavatelem požadováno ocenění lesního majetku pro jiné účely než daňové, a je přitom požadována cena zjištěná, měl by se lesní majetek ocenit takto:

Cena lesního pozemku podle $\S 7 \mathrm{OV}$ $+$

Cena lesního porostu podle $\S 40 \mathrm{OV}$ $=$

Zjištěná cena lesního majetku pro jiné účely (než je daň z nabytí věci nemovité)
OV neuvádí, k jakému účelu je možné ocenit lesní porost podle $\S 40$. Má se za to, že lze lesní majetek ocenit podle $§ 7$ (lesní pozemek) a $§ 40$ lesní porost pro účely majetkových újem. Vedle toho je třeba mít na zréeteli, že ZOM a OV a následně také Komentár ministerstva financí ČR k určování ceny obvyklé [1] uvádí, že nelze-li určit cenu obvyklou, určí se cena zjištěná. Nelze však mít za správné a logické, že cena obvyklá se v daném případě rovné ceně zjištěné, a to proto, že cenu obvyklou oceňovatel nezná. V zásadě je požadovaná cena obvyklá, kterou v daném př́ípadě nebylo možné určit, nahrazena cenou zjištěnou. To pak také musí být uvedeno v závěrečném výroku o ceně lesního majetku v rekapitulaci znaleckého posudku.

\section{Cena zjištěná jako substituent ceny obvyklé}

Pokud zadavatel požaduje cenu obvyklou cenu podle $\S 2$ ZOM, kterou však není objektivně možné určit a zpracovatel dojde k závěru, že nelze určit cenu obvyklou, může určit cenou zjištěnou:

Cena lesního pozemku podle $\S 7 \mathrm{OV}$

$+$

Cena lesního porostu podle $\S 40 \mathrm{OV}$

$=$

Zjištěná cena lesního majetku, která může být použita, jako substituent ceny obvyklé v případech, kdy nelze určit cenu obvyklou

\section{Cena obvyklá}

Pokud zadavatel výslovně požaduje obvyklou cenu podle $\S 2$ odst. 1 (ZOM) je nutné tuto cenu určit porovnáním s využitím referenčních vzorků realizovaných prodejů porovnatelných lesních majetků. V současnosti, kdy Český úřad zeměměřický a katastrální umožňuje přístup $\mathrm{k}$ cenovým údajům včetně možnosti získat kopii příslušné kupní smlouvy, se již nelze odvolávat na obtížné získávání cen z kupních smluv. V důvodové zprávě $\mathrm{k}$ ZOM a také v komentár̆i ministerstva financí ČR k určování ceny obvyklé se uvádí, že nelze používat nabídkové ceny. Pokud i přesto znalec nabídkovou cenu použije, měl by to odůvodnit v kontextu účelu ocenění (př́ípadně se souhlasem zadavatele). $\mathrm{V}$ př́padě soudních sporů může být dokonce takové ocenění považováno za sporné, s tím že bude předmětem sporu také závaznost/nezávaznost důvodové zprávy a komentáře MF. Nutno si také představit situaci, že krátce po odevzdání ocenění se nabízený majetek prodá za diametrálně jinou cenu, což může zpochybnit výsledek ocenění.

Výsledkem porovnávací metody je cena lesního majetku (cena lesního pozemku s lesním porostem). Nelze paušálně tvrdit, že porovnání s využitím realizovaných prodejů není možné. Naopak je dnes známo, že pro určité majetky je toto ocenění vhodné, někdy dokonce jako jediné možné. Porovnání na základě realizovaných prodejů má podle našeho názoru již svůj nezastupitelný význam při oceňování lesních majetků. Pokud skutečně porovnání není možné, oceňovatel může podle situace a účelu přistoupit k nahrazení ceny obvyklé cenou zjištěnou, případně nahradit obvyklou cenu tržní hodnotou.

\section{Tržní hodnota}

Pokud zadavatel požaduje tržní hodnotu lesního majetku, zpracovatel postupuje kombinací nákladového, porovnávacího a výnosového přístupu. Individuální přístup se podřizuje charakteru oceňovaného lesního majetku. 
S narůstající výměrou lesního majetku, rovnoměrnou věkovou strukturou lesních porostů je aplikace tří oceňovacích př́stupů vhodnější, s patrně vůdčím postavením výnosového př́ístupu s využitím kapitalizace věčné renty. $V$ zásadě takové ocenění lesního majetku principiálně přechází do metod ocenění lesního podniku.

Při ocenění lesních majetků malých výměr je kombinace tři přístupů závislá především na věkové struktuře lesních porostů.

Např́íklad při ocenění malé výměry lesního pozemku bez lesního porostu (holiny) je porovnání jediné možné.

Při ocenění malé výměry lesního pozemku s lesním porostem, který lze okamžitě těžit, lze kombinovat porovnávací př́istup s prístupem výnosovým.

Při ocenění malé výměry lesního pozemku s lesním porostem, který bude možné těžit, lze kombinovat nákladový a výnosový přístup, zaleží však na délce období, kdy možnost těžeb skutečně nastane.

Závěrem autoři zdůrazňují, že nebylo ambicí příspěvku vyřešit problematiku oceňování lesních majetků v celé šíri. Hlavním cílem bylo usnadnit orientaci v současné terminologii a legislativě, která by měla být vyřešena novelizací zákona o oceňování majetku.

\section{Poděkování}

Příspěvek byl zpracován na základě řešení projektu NAZV č. QJ1530032 „Aktuální a strategické možnosti trvale udržitelného poskytování funkcí lesa a služeb polyfunkčního lesního hospodářství veřejnosti z hlediska sociálně-ekonomického, politického a právního v České republice.“

\section{LITERATURA}

[1] Komentáře. Komentář k určováni obvyklé ceny. Ministerstvo financí ČR [online]. Praha: Ministerstvo financí ČR, (C) 2014 [cit 2018-12-30]. Dostupné z: https://www.mfcr.cz/cs/verejnysektor/ocenovani-majetku/komentare/komentar-k-urcovaniobvykle-ceny-oceneni-19349

[2] ZAZVONIL, Z. Odhad hodnoty nemovitostí. Ekopress, 2016 Praha, 454 s. ISBN 978-80-86929-88-0.

[3] KALABIS, P. Studie koexistence dvou oceňovacích systémů v ČR (administrativní a tržní). Česká komora odhadců majetku, Odhadce 2011, XVII/1, s. 33-42. ISSN 1213-8223.
[4] POLÁK, P. Oceňování majetku státu. S majetkem státu se musí řádně hospodařit. Česká komora odhadců majetku, Odhadce 2011, XVII/3-4, s. 57-60. ISSN 1213-8223.

[5] ZÁDRAPA, R. Možnosti tržního oceňování lesních majetků. Česká komora odhadců majetku, Odhadce 2012, VIII/3, s 33-38. ISSN 1213-8223.

[6] ZÁDRAPA, R. Oceňování lesa obvyklou cenou a tržní hodnotou. Semináŕ (studijní materiály), 2018.

[7] Zákon č. 289/1995 Sb., o lesích a o změně některých zákonů, ve znění pozdějších předpisů. In: ASPI [právní informační systém]. Praha: Wolters Kluwer ČR [cit 2018-12-30]. Dostupné také z: https://www.zakonyprolidi.cz/cs/1995-289.

[8] Zákon č. 151/1997 Sb., o oceňování majetku a o změně některých zákonů, ve znění pozdějších předpisů. In: $A S P I$ [právní informační systém]. Praha: Wolters Kluwer ČR [cit 2018-12-30]. Dostupné také z: https://www.zakonyprolidi.cz/cs/1997-151.

[9] BRADÁČ, A. a kol. Teorie a praxe oceňováni nemovitých věcí. Akademické nakladatelství CERM, s.r.o., 2016 Brno, 790 s. ISBN: 978-80-7204-930-1.

[10] ZAZVONIL, Z. Oceňování nemovitostí: výnosový přistup: textová část - cvičení. Oeconomica, 2015 Praha, $52 \mathrm{~s}$. ISBN: 978-80-245-1525-0.

[11] Vyhláška č. 441/2013 Sb., k provedení zákona o oceňování majetku, ve znění pozdějších předpisů. In: ASPI [právní informační systém]. Praha: Wolters Kluwer ČR [cit 2018-12-30]. Dostupné také z: https://www.zakonyprolidi.cz/cs/2013-441

[12] IVSC: Mezinárodní oceňovaci standardy 2017. EKOPRES, S.R.O., 2017, 237 s. ISBN 978-80-87865-44-6.

[13] ČESKÁ KOMORA ODHADCŮ MAJETKU: Metodický pokyn pro tržnínetržní oceňování nemovitých věcí. 2016

[14] MATĚJIČEK, J., ZÁDRAPA, R. Oceňování lesa. Lesnická a dřevařská fakulta, Mendelova univerzita v Brně, Brno 2016, 161 s., bez ISBN. Dostupné z: https://akela.mendelu.cz/ xcep1/ inobio/skripta/Ocenovani lesa skripta.pdf.

[15] VÝZKUMNÝ PROJEKT GRANTOVÉ SLUŽBY LČR: Diferenciální lesní renta. 2018. Dostupné z: https://lesycr.cz/ grantova-sluzba-projekt/diferencialni-lesni-renta/.

[16] MATĚJÍČEK, J. a kol.: Úroková míra v lesnictví. Lesnická práce, s.r.o., Kostelec nad Černými lesy 2013, 160 s. ISBN 978-80-7458-049-9.

[17] VALA, V., BŘEZINA D., SADÍLEK, A., HAKL, F. Oceňování lesních majetků. Sborník přispěvků konference Expert Forensic Science Brno 2019, s. 415-428. ISBN 78-80-214-5708-9. Dostupné z: http://exfos.cz/wp-content/uploads/2019/02/ ExFoS_2019.pdf

\section{Správná citace:}

Vala, V., Březina D., Sadílek, A., Hakl, F. Oceňování lesních majetků. Soudní inženýrství, 2019, 30(3), 29-36. DOI: http://dx.doi. org./10.13164/SI.2019.3.29. ISSN 1211-443X. 